Jurnal Intelektualita: Keislaman, Sosial, dan Sains

Volume 7, Nomor 2, Desember 2018

ISSN: 2303-2952 (print)

DOI: https://doi.org/10.19109/intelektualita.v7i2.2728

\title{
Penerapan Sistem Publikasi Informasi Humas dalam Meningkatkan Validitas Informasi di Website Kementerian Agama Provinsi Sumatera Selatan
}

\author{
Riska Amelia \\ Program Studi Komunikasi Penyiaran Islam \\ Universitas Islam Negeri Raden Fatah Palembang \\ Email: riskaamelia_uin@radenfatah.ac.id
}

\begin{abstract}
Abstrak
This research was carried out on public relations in the Ministry of Religion of South Sumatra Provincewhich has implemented an information publication system to improve the validity of information on the website of the Ministry of Religion of South Sumatra Province. The background of this research isbased on Law No. 14 of 2008concerning Public Information Openness and ISO / IEC 20071 of 2009 concerning Information Security Management System Requirements. The work unit in the Ministry of Religion of South Sumatra implements a standard for the control of online media, namely the information publication system.Thisinformation publication system with the purpose of controlling information published on the website. This research uses qualitative data, where the primary data sources are public relations staff, SOP information system and website of the Ministry of Religion of South Sumatra Province.The theorythis research is the Grunig and Hunt Situation Theory of public information needs and Shannon and Weaver's information theory.The results of this research are the application of this information publication system with 5 control books can improve the validity of information because the published information can be more clearly and accurately.
\end{abstract}

Keywords: Public Relations, Website, Validity of Information, Information Publication

Istilah public relations sering diterjemahkan sebagai humas yang terdiri dari semua bentuk komunikasi yang terselenggara antara organisasi yang bersangkutan dengan siapa saja yang berkepentingan dengannya [1]. Dalam menjalankan fungsinya setiap perusahaan atau organisasi tidak terlepas dari dukungan seorang humas baik itu perusahaan kecil atau juga perusahaan besar.

Pada awalnya, tugas humas adalah memberikan penerangan untuk meningkatkan hubungan baik dengan mereka yang pendapatnya berpengaruh bagi organisasi dalam menentukan kebijaksanaa yang terbaik. Selanjutnya berkembanglah tugas untuk meningkatkan saling pengertian antara organisasi dengan kelompok masyarakat [2].

Humas sangat berperan penting dalam menciptakan citra positif bagi perusahaan. Dalam hal ini seorang humas diperlukan memiliki komunikasi yang baik untuk bisa meningkatkan mutu dan kualitas suatu perusahaan.

Menciptakan komunikasi dua arah secara timbal balik dengan menyebarkan informasi dari perusahaan kepada publik merupakan salah satu tugas utama public relations atau humas. Informasi merupakan salah satu aset penting dari suatu instansi. Kemampuan untuk menyediakan informasi yang akurat dan cepat menjadi suatu hal yang penting dari suatu perusahaan atau instansi. 


\section{Riska Amelia}

Penerapan Sistem Publikasi Informasi Humas dalam Meningkatkan Validitas Informasi di Website Kementerian Agama Provinsi Sumatera Selatan

Kegiatan menyampaikan informasi disebut dengan kegiatan publikasi. Publikasi adalah kegiatan mengenalkan perusahaan sehingga umum (publik dan masyarakat) dapat mengenalnya [3].

Sub Bagian informasi dan humas Kantor Wilayah Kementerian Agama provinsi Sumatera Selatan telah menyiapkan diri untuk menerapkan kerja pengelolaan website, baik surel ataupun media sosial dengan standar Sistem Manajemen Keamanan Informasi yang sesuai dengan standar SNI 27001.

Pengelolaan keamanan sistem informasi harus dimulai ketika sebuah sistem informasi dibangun, bukan hanya sebagai pelengkap sebuah sistem informasi. Dengan adanya pengelolaan keamanan sistem informasi yang baik, maka diharapkan satuan kerja dapat memprediksi resiko-resiko yang muncul akibat penggunaan sistem informasi sehingga dapat menghindari atau mengurangi resiko yang mungkin dapat merugikan. Keamanan sistem informasi merupakan tanggungjawab semua pihak/seluruh pegawai yang ada di dalam lingkungan Kantor Wilayah Kementrian Agama provinsi Sumatera Selatan.

Untuk mengatasi hal itu diperlukan penerapan Sistem Manajemen Keamanan Informasi (SMKI) yang diakui secara internasional yakni standar internasional kemananan informasi ISO 27001. Dengan menerapkan ISO/IEC 27001 akan meningkatkan kepercayaan publik terhadap informasi yang dihasilkan dan diproses oleh sebuah instansi/organisasi serta meningkatkan jaminan kualitas dari sebuah informasi.

Dalam meningkatkan validitas sebuh informasi humas Kanwil Kemenag provinsi Sumatera Selatan menetapkan standar operasional publikasi informasi publik mulai dari tahap pencatatan informasi yang akan dipublikasi, tahap verifikasi informasi, tahap digitalisasi, tahap upload dan terakhir tahap publish. Termasuk kontrol surel dan medsos, serta kontrol hak akses [4].

Adapun tujuan dari prosedur publikasi informasi diterapkan Sub Bagian informasi dan Humas Kementerian Agama provinsi Sumatera Selatan untuk menjaga keaslian sumber informasi yang dipublikasikan ke masyarakat, menerapkan sistem keamanan informasi (SMKI) di lingkungan Kantor WilayahKementrian Agama provinsi Sumatera Selatan, serta meningkatkan pelayanan kepada masyarakat [5].

\section{Hasil dan Pembahasan}

Banyaknya penyebaran pemberitaan palsu atau hoax akhir-akhir ini di berbagai media online membuat Tim TIK Kantor Wilayah Kementerian Agama Provinsi Sumatera Selatan menyiapkan langkah-langkah antisipasi dengan menerapkan Tata Kelola Keamanan Informasi atau yang lebih dikenal dengan Sistem Manajemen Keamanan Informasi (SMKI), sistem ini diyakini bisa mencegah atau menghindari penyebaran informasi atau berita palsu [4].

Kanwil Kemenag Sumsel sudah menyiapkan berbagai dokumen SMKI. Penyelenggaraan Sistem Manajemen Keamanan Informasi ini dilaksanakan berdasarkan:

1. Undang-Undang No.11 tahun 2008 tentang Informasi dan Transaksi elektronik

2. Undang-undang N0. 14 tahun 2008 tentang Keterbukaan Informasi Publik 


\section{Riska Amelia}

Penerapan Sistem Publikasi Informasi Humas dalam Meningkatkan Validitas Informasi di Website Kementerian Agama Provinsi Sumatera Selatan

3. Surat edaran Menteri Nomor 5/SE. M.KOMINFO/07/2011 tentang Penerapan Tata Kelola Keamanan Informasi bagi Penyelenggara Pelayanan Publik

4. Siaran Pers No. 127/PIH/KOMINFO/6/2009 tentang Konsultasi Publik tentang Rancangan Peraturan Pemerintah Tentang Penyelenggaraan Sistem Elektronik (eGoverment) di Instansi Pusat dan Daerah

5. SNI ISO/IEC 20071 tahun 2009 tentang Persyaratan Sistem Manajemen Keamanan Informasi.

Sebagai implementasi Sistem Manajemen Keamanan Informasi, satuan kerja di Kemenag Sumsel menerapkan standar kontrol penggunaan media online yaitu sistem publikasi informasi.

Sistem publikasi informasi publik dilaksanakan sebagai kontrol terhadap tingkat validitas informasi yang akan diterbitkan melalui website atau media sosial oleh seorang admin website, setidaknya ada buku data, surat ataupun informasi yang harus diisi oleh admin website.

Adapun prosedur untuk mempublikasikan informasi adalah menertibkan kepemilikan penanganan media online dan media sosial melalui Surat Keputusan Kepala kantor Wilayah Kementerian Agama Provinsi Sumatera Selatan Nomor 349 Tahun 2017 tanggal 29 Maret 2017dan pengelolaan standar publikasi informasi dengam mengisi 5 buku kontrol yang terdiri dari:

a. Buku registrasi informasi publik subbag informasi dan humas

Buku registrasi merupakan tahap pertama dalam prosedur sistem publikasi informasi. Informasi yang akan dipublikasikan di website Kementerian Agama Provinsi Sumatera Selatan harus diregistrasi terlebih dahulu agar informasi yang masuk bisa terdata dan menjadi arsip bagi humas di Kementerian Agama Provinsi Sumatera Selatan jika sewaktu-waktu diperlukan. Buku Registrasi ini dicatat oleh penerima informasi yang masuk dan langsung dilakukan registrasi. Sesuai dengan teori informasi Grunig and Hunt adanya Information Source (sumber informasi), dalam buku registrasi ini harus diketahui dari mana sumber informasi yang akan dipublikasikan.

b. Buku verifikasi informasi publik subbag informasi dan humas

Buka verifikasi merupakan tahap kedua dalam prosedur sistem publikasi informasi. Informasi yang telah didaftarkan atau diregistrasi tidak langsung bisa dipublikasikan di website Kementerian Agama Provinsi Sumatera Selatan, akan tetapi di verifikasi terlebih dahulu oleh admin webiste yaitu tim website dan tim PPID. Tahap verifikasi inilah yang menentukan informasi tersebut bisa ke proses selanjutnya atau tidak bisa dilanjutkan.

c. Buku digitalisasi informasi publik subbag informasi dan humas

Buku digitalisasi adalah tahap ketiga dalam prosedur sistem publikasi informasi. Informasi yang akan digitalisasi ini biasa berupa surat ataupun pengumuman. Informasi yang telah diverifikasi selanjutnya akan diserahkan kepada petugas humas yang akan melakukan proses digitalisasi yaitu berupa hasil scan informasi 
Riska Amelia

Penerapan Sistem Publikasi Informasi Humas dalam Meningkatkan Validitas Informasi

di Website Kementerian Agama Provinsi Sumatera Selatan

yang akan dipublikasikan. Petugas humas yang melakukan digitalisasi harus mencatat proses digitalisasi pada buku ini.

d. Buku upload informasi publik subbag informasi dan humas

Buku upload merupakan tahap keempat dalam prosedur sistem publikasi informasi. Informasi yang telah melewati tiga proses yaitu registrasi, verifikasi dan digitalisasi telah bisa di upload di website Kementerian Agama Provinsi Sumatera Selatan. Petugas humas yang melakukan proses upload harus mencatat proses upload informasi di buku kontrol upload informasi.

e. Buku publikasi informasi publik subbag informasi dan humas

Buku publikasi informasi ini merupakan proses terakhir dalam prosedur sistem publikasi informasi. Informasi yang telah melewati empat proses yakni registrasi, verifikasi, digitalisasi dan upload bisa langsung di publikasikan di website Kementerian Agama Provinsi Sumatera Selatan. Dengan proses publikasi ini, maka informasi yang di telah di upload bisa dilihat oleh masyarakat pengunjung website Kementerian Agama Provinsi Sumatera Selatan. Petugas humas yang melakukan proses publikasi ini juga harus mencatat semua proses tersebut di buku publikas informasi.

Dengan adanya penerapan kegiatan publikasi ini informasi lebih terdata dan terkontrol dengan baik, membiasakan karyawan untuk lebih bertanggung jawab atas informasi yang disebarkan kepada khalayak, dengan adanya penerapan sistem publikasi ini, informasi yang disebarkan lebih terpercaya dan jelas sumbernya dan sistem publikasi iniformasi ini bisa menjadi arsip Kemenag Sumsel yang bisa dicek kembali saat dibutuhkan serta memudahkan menemukan rincian informasi yang telah dipublikasikan.

Contoh penerapan teori informasi Shannon dan Weaver terhadap kegiatan yang ada di humas Kementerian Agama Provinsi Sumatera Selatan yang di upload dalam informasi penting di website Kementerian Agama Provinsi Sumatera Selatan yaitu:

1. Information Source: Merupakan sumber ataupun asal informasi yang akan dipublikasikan, misalnya informasi dari Direktorat Jendral Pendidikan Islam mengenai Ekspo Sains Madrasah pada KSM Tahun 2018

2. Transmitter: Pemancar yang dalam hal ini menggunakan media online yang berarti menggunakan koneksi internet.

3. Channel: Media untuk menyalurkan sebuah informasi yaitu website resmi Kementerian Agama Provinsi Sumatera Selatan.

4. Receiver: Penerima informasi yang disampaikan adalah seluruh Madrasah yang ada di Sumatera Selatan.

5. Destination: Sasaran dalam informasi ini adalah siswa/i madrasah yang akan mengikuti pameran (Ekspo) dalam bidang sain yang berupa hasil karya siswa madrasah

6. Noise Source: Berupa gangguan yang biasanya terjadi pada Channel atau media, dalam hal ini bisa terjadi pada gangguan website yang bermasalah seperti jaringan yang tidak bisa menghubungkan ke lawan website Kementerian Agama Provinsi Sumatera Selatan. 


\section{Riska Amelia}

Penerapan Sistem Publikasi Informasi Humas dalam Meningkatkan Validitas Informasi di Website Kementerian Agama Provinsi Sumatera Selatan

Penerapan sistem publikasi ini dilaksanakan dengan tujuan agar terhindar dari berita palsu atau tidak valid. Dengan diterapkannya sistem publikasi ini diharapkan bisa meningkatkan validitas informasi di website Kementerian Agama Provinsi Sumatera Selatan. Berdasarkan dari hasil pengamatan yang telah dilakukan, ada beberapa indikator penting dalam sistem publikasi informasi dengan 5 buku kontrol yang bisa meningkatkan validitas sebuah informasi, sehingga informasi yang dipublikasikan di website Kementerian Agama Provinsi Sumatera Selatan bisa dipertanggungjawabkan dan bisa menjadi data atau informasi yang akurat.

Hal ini disampaikan dalam wawancara dengan Kasubag Informasi dan Humas bapak H. Seafudin Latif, S.Ag M.Si, beliau mengatakan bahwa:

"Karena dari awal semua informasi yang akan dipublikasikan semuanya tecatat dengan jelas di buku 5 buku kontrol publikasi informasi, sehingga kami memiliki arsip dan bukti yang jelas jika ada kesalahan dalam sebuah informasi yang dipublikasika."

Bapak M. Akhfasyi, S.Kom, juga mengatakan bahwa:

"Dalam prosedur publikasi informasi itu ada yang namanya verifikasi, itulah gunanya verifikasi untuk meningkatkan validitas informasi. Verifikasi dilakukan bukan hanya dengan 1 orang tapi yang memverifikasi informasi tersebut ada 2 orang, ketika 2 orang yang memverifikasikan informasi tersebut mengatakan informasi itu lanjut untuk ke prosedur selanjutnya, infromasi tersebut dinyatakan sudah bisa untuk digitalisasikan, hal inilah yang bisa meningkatkan validitas informasi, karena sumber informasinya jelas dan yang memverifikasinya pun bukan hanya 1 orang tapi 2 orang, dengan begitu informasi yang ada telah kita jaga keabsahannya dan layak untuk di publish."

Dengan begitu hal yang menyebabkan sistem publikasi informasi ini dapat meningkatkan validitas informasi yaitu karena setiap informasi yang akan di publikasikan tercatat dan terdata dengan jelas mulai dari sumber informasi tersebut, siapa yang membuat informasi tersebut, yang memverifikasinya dan yang mempublikasikannya di website Kementerian Agama Provinsi Sumatera Selatan. Dengan adanya data yang lengkap di setiap informasi yang akan dipublikasikan, ketika ada suatu kesalahan pada informasi yang telah dipublikasikan tim humas bisa menelusuri siapa yang membuat informasi tersebut sehingga informasi tersebut bisa di kontrol.

Pada dasarnya pengelolaan sistem publikasi informasi di website Kementerian Agama Provinsi Sumatera Selatan terlaksana dengan baik. Tetapi ada satu faktor yang menghambat pelaksanaan penerapan sistem publikasi informasi ini yaitu kebiasaan dari SDM atau pegawai humas.

Mengubah suatu hal yang sebelumnya belum pernah dilakukan menjadi suatu kebiasaan yang harus dilakukan setiap akan mempublikasikan informasi di website dengan mengisi 5 buku kontrol ini agak sedikit membutuhkan waktu.

Hal ini disampaikan oleh salah satutim website humas Miftahul Jannah, S.Sos yang mengatakan bahwa: 


\section{Riska Amelia}

Penerapan Sistem Publikasi Informasi Humas dalam Meningkatkan Validitas Informasi

di Website Kementerian Agama Provinsi Sumatera Selatan

"Kendala dalam penerapan sistem publikasi informasi ini adalah kebiasaan, karena pada awal penerapan 5 buku kontrol ini para pegawai merasa terlalu banyak proses yang dilakukan, terlebih harus mengisi 5 buku kontrol sebelum melakukan publikasi informasi di website Kementerian Agama Provinsi Sumatera Selatan sehingga membuat pegawai merasa semakin banyak pekerjaan yang harus mereka kerjakan."

Terkait dengan kenadala tersebut M. Akhafasyi juga mengatakan bahwa:

"Untuk menjaga agar sistem publikasi informasi ini berjalan dengan sesuai prosedur, maka sesama staf humas harus bisa saling mengingatkan dan tidak menganggap remeh walaupun hanya mencatat, memverifikasi, mendigitalisasi, upload dan publish itu sangat sederhana tapi tetap harus saling mengingatkan agar langkah-langkah tersebut terlaksanakan dan tercatat dalam buku kontrol informasi."

Kendala untuk melaksanakan prosedur sistem publikasi informasi ini juga ada pada SDM itu sendiri yaitu tim humas Kementerian Agama Provinsi Sumatera Selatan. Kerena tim humas harus bisa membagi pekerjaan mereka sesuai dengan uraian pekerjaan mereka masing-masing dan sesuai dengann SOP yang ada, jika tidak dilaksanakan denga baik maka penerapan sistem publikasi informasi ini juga tidak akan terlaksanakan dengan baik. Seperti yang diungkapkan oleh Kasubag Informasi dan Humas H. Saefudin Latif S.Ag M.Si. beliau megatakan bahwa:

"Agar penerapan sistem informasi ini tetap berjalan sesuai dengan prosedurnya, maka staf humas harus bisa bekerja sesuai dengan uraian tugas masing-masing dan mereka harus bekerja sesuai dengan SOP yang ada. Jika staf sudah bekerja sesuai dengan tugasnya dan sesuai dengan SOP yang ada insyaAllah semua berjalan seperti yang diharapkan [4]."

Seiring berjalannya penerapan sistem publikasi informasi ini yang tetap dilakukan secara terus menerus, pegawai humas pada akhirnya mulai terbiasa dengan prosedur yang diterapkan dalam publikasi informasi di website dan pegawai humas juga bisa merasakan bahwa pentingnya penerapan sistem publikasi informasi ini sebagai bentuk kontrol informasi dari berita yang kurang valid.

Hasil dari penerapan sistem publikasi informasi humas di website Kementerian Agama Provinsi Sumatera Selatan yaitu dengan berhasilnya mendapatkan prestasi sebagai peringkat 1 keterbukaan informasi publik tingkat Provinsi Sumatera Selatan Tahun 2017 kategori instansi vertikal dan rumah sakit pemerintah pada tanggal 6 Desember 2017 di Palembnag yang disahkan oleh ketua Informasi Provinsi Sumatera Selatan bapak Herlambang, SH, MH serta Gubernur Sumatera Selatan bapak H. Alex Noerdin. 
Riska Amelia

Penerapan Sistem Publikasi Informasi Humas dalam Meningkatkan Validitas Informasi di Website Kementerian Agama Provinsi Sumatera Selatan

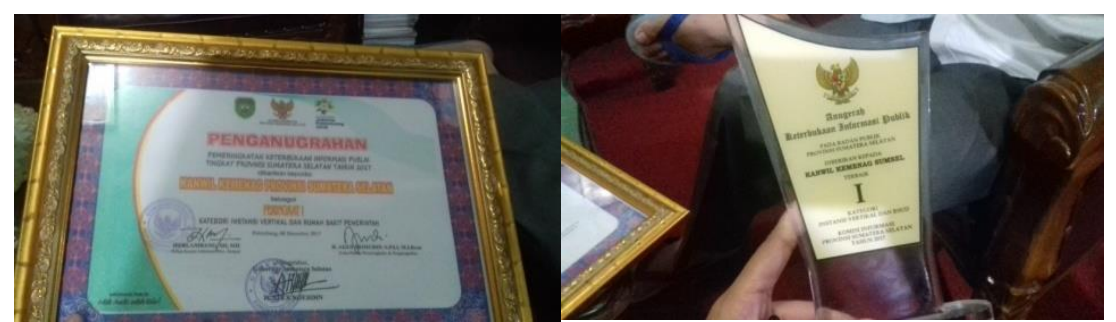

Gambar 12: Penganugrahan keterbukaan informasi publik

Penerapan sistem publikasi informasi ini bisa meningkatkan citra positif bagi humas Kementerian Agama Provinsi Sumatera Selatan, dengan adanya penganugrahan sebagai instansi peringkat pertama kategori keterbukaan informasi publik itu berarti publik telah percaya dengan informasi yang yang dipublikasikan oleh humas di website Kementerian Agama Provinsi Sumatera Selatan.

Selain itu hasil dari penerapan sistem publikasi informasi ini juga bisa menjadi evaluasi kinerjabagi tim humas dan sebagai laporan terkait informasi yang telah ditelah dipublikasikan di website Kementerian Agama Provinsi Sumatera Selatan dan dengan adanya penerapan sistem informasi ini tim humas lebih bisa bertanggung jawab dengan informasi yang akan dipublikasikan.

Dengan diterapkannya sistem publikasi informasi ini hasil yang dapat diperoleh sesuai dengan surat keputusan Kepala Kantor Wilayah Kementerian Agama Provinsi Sumatera Selatan nomor 349 tahun 2017 yaitu:

1. Menjaga Kerahasiaan, ketersediaan dan integritas serta keamanan informasi pada satuan kerja kantor wilayah Kementerian Agama Provinsi Sumatera Selatan.

2. Mencegah informasi hoax atau palsu dengan penerapan 5 buku kontrol informasi publik

3. Dapat mengelola informasi secara profesional dan bertanggung jawab.

\section{Kesimpulan}

Berdasarkan deskripsi, analisis dan pembahasan data maka dapat disimpulkan bahwa penerapan sistem publikasi informasi humas di website Kementerian Agama Provinsi Sumatera Selatan dalam meningkatkan validitas informasi berjalan dengan baik sesuai prosedur yang telah ditetapkan. Sistem publikasi informasi ini bisa menjadi salah satu contoh dan pembelajaran bagi instansi lain untuk mengontrol informasi yang akan dipublikasikan dan sebagai sarana keterbukaan informasi publik.

Petugas Humas dan Informasi Kementerian Agama Provinsi Sumatera Selatan telah menerapakan dan melaksanakan sistem publikasi informasisesuai prosedur yakni dengan mengisi 5 buku yang telah disediakan antara lain berupa buku registrasi, verifikasi, digitalisasi, upload dan publikasi informasi. Penerapan sistem publikasi informasi berguna sebagai media untuk menjaga keabsahan informasi dan meningkatkan validitas sebuah informasi yang akan dipublikasikan di website Kementerian Agama Provinsi Sumatera Selatan.

Adapun hasil dan efek positif dari penerapan sistem publikasi Informasi terhadap Kantor Wilayah Kementerian Agama Provinsi Sumatera Selatan, diantaranya: 


\section{Riska Amelia}

Penerapan Sistem Publikasi Informasi Humas dalam Meningkatkan Validitas Informasi

di Website Kementerian Agama Provinsi Sumatera Selatan

1. Dengan adanya sistem publikasi informasi yang diterapkan melalui 5 buku kontrol publikasi ini merupakan salah satu cara untuk meningkatkan validitas sebuah informasi dikarenakan sebelum informasi dipublikasikan di website Kementerian Agama Provinsi Sumatera Selatan telah dilakukan proses penyaringan informasi terlebih dahulu, sehingga informasi yang ada terjaga keabsahannya dan siap untuk dipublikasikan.

2. Dengan adanya sistem publikasi ini, informasi lebih terdata dan terkontrol dengan baik.

3. Membiasakan karyawan untuk lebih bertanggung jawab atas informasi yang disebarkan kepada khalayak.

4. Dengan adanya penerapan sistem publikasi informasi ini, informasi yang disebarkan lebih terpercaya dan jelas sumbernya.

5. Sebagai arsip Kementerian Agama Provinsi Sumatera Selatan yang bisa dicek kembali saat dibutuhkan ketika terjadi permasalahan yang berhubungan dengan informasi tersebut.

6. Memudahkan menemukan rincian informasi yang telah dipublikasikan. 
Riska Amelia

Penerapan Sistem Publikasi Informasi Humas dalam Meningkatkan Validitas Informasi

di Website Kementerian Agama Provinsi Sumatera Selatan

\section{Daftar Pustaka}

[1] M. Linggar Anggoro, Teori dan Profesi Kehumasan. Jakarta: Bumi Aksara, 2008.

[2] John Tondowijodjo, Dasar dan ArahPublic Relations. Jakarta: PT Grasindo, 2002.

[3] Rachmad Kriyantono, ,Public Relation Writing. Jakarta: Kencana, 2012.

[4] Saefudin Latif, "Cegah Berita Hoax dengan Penerapan SMKI," Rukun Umat Nomor.85, p. 3, 2017.

[5] Tim humas, SOP Informasi Publik, Petunjuk pelaksanaan dan petunjuk teknis. Palembang: Kanwil Kemenag Sumsel, 2017. 
Riska Amelia

Penerapan Sistem Publikasi Informasi Humas dalam Meningkatkan Validitas Informasi di Website Kementerian Agama Provinsi Sumatera Selatan 